\title{
Numerical and DNA : DNA Reassociation Analyses of Erwinia rubrifaciens and Other Members of the Enterobacteriaceae
}

\author{
By H. R. AZAD† AND C. I. KADO* \\ Department of Plant Pathology, University of California, Davis, California 95616, U.S.A.
}

(Received 29 January 1980; revised 20 March 1980)

Phenetic data on 75 strains of Erwinia and other representative genera of the Enterobacter-
iaceae were collected and analysed using two numerical taxonomic methods. In both methods
the same subclusters were recovered. The subclusters, however, were defined at different
similarity levels and were classified into clusters of different composition. Erwinia rubri-
faciens strains formed a very tight, homogeneous subcluster, completely distinct and readily
distinguishable from other Erwinia and enterobacteria species studied. DNA: DNA hybridi-
zations between $E$. rubrifaciens and Erwinia and Shigella species were analysed to corrobo-
rate the numerical classifications. A good correlation between the numerical and DNA:
DNA hybridization analyses was found and provided sufficient evidence for not supporting
the previously proposed subspecific taxonomic position of $E$. rubrifaciens. The data clearly
showed that $E$. rubrifaciens is a separate species in its own right. Based on the existence of
very high genetic relatedness and high similarities in phenetic characters among $E$. rubri-
faciens strains and the confinement of the pathogen to the state of California, the hypothesis
is offered that $E$. rubrifaciens originated from a single source.

\section{INTRODUCTION}

A bacterium that causes deep bark canker disease of Persian walnuts (Juglans regia L.) was first described as Erwinia rubrifaciens by Wilson et al. (1967). Thorough biological and epidemiological studies of the disease have been reported (Schaad \& Wilson, 1970a, $b$, 1971 a, b; Schaad et al., 1973; Gardner \& Kado, 1973; Kado \& Gardner, 1977; Kado et al., 1977 ) but the taxonomic position of $E$. rubrifaciens remains unclear. Erwinia rubrifaciens was thought to share phenotypic characters with $E$. amylovora and thus was ranked as a variety of $E$. amylovora (Dye, 1968). DNA:DNA hybridization experiments did not support these findings because of the low (13 to $15 \%$ ) DNA homologies between $E$. rubrifaciens and E. amylovora (Gardner \& Kado, 1972; Brenner et al., 1972; Murata \& Starr, 1974). Recently, Young et al. $(1978 a, b)$ have included $E$. rubrifaciens as a pathovar of $E$. quercina on the basis of a few physiological and biochemical tests.

The taxonomic status of $E$. rubrifaciens therefore seemed to remain in a state of flux and could only be resolved by detailed comparative studies. We have examined $E$. rubrifaciens strains from all areas where they occur naturally and in this paper we report comparative analyses of these strains with other enterobacteria.

\section{METHODS}

Bacterial strains. Some $E$. rubrifaciens strains were obtained from the laboratory culture collection; others were isolated during the summers of 1976 and 1977 from infected walnut trees located in various counties of California (Table 1) using methods previously described (Wilson et al., 1967; Schaad \& Wilson, $1971 b$; Kado et al., 1977). The remaining strains studied are listed in Table 2.

$\dagger$ Present address: Department of Plant Protection, Shiraz University, Shiraz, Iran. 
Table 1. Erwinia rubrifaciens strains studied

\begin{tabular}{|c|c|c|}
\hline Strain & California county of isolation & Source* \\
\hline 6D365 & Tehama & This paper \\
\hline 6D 366, 6D 373 & Glenn & This paper \\
\hline 6D374, 6D 375, 6D376, 6D379 & Butte & This paper \\
\hline 6D 345 & Colusa & N. Schaad, UC Davis \\
\hline 6D369, 6D381 & Yuba & This paper \\
\hline 6D372, 6D368 & Sutter & This paper \\
\hline 6D360, 6D356 & Sutter & N. Schaad, UC Davis \\
\hline 6D3, 6D34 & Yolo & E. E. Wilson, UC Davis \\
\hline $6 \mathrm{D} 330$ & Yolo & Lee Jackson, UC Davis \\
\hline 6D370 & Yolo & This paper \\
\hline 6D364, 6D380 & Solano & This paper \\
\hline 6D377 & Contra Costa & This paper \\
\hline 6D361 & San Joaquin & N. Schaad, UC Davis \\
\hline 6D327 & Stanislaus & J. Gardner, UC Davis \\
\hline 6D331, 6D332, 6D337, & & \\
\hline 6D339, 6D348, 6D349 & Stanislaus & N. Schaad, UC Davis \\
\hline $\begin{array}{l}\text { 6D343, 6D344 } \\
\text { 6D363 }\end{array}$ & Merced & $\begin{array}{l}\text { N. Schaad, UC Davis } \\
\text { W. Moller, UC Davis }\end{array}$ \\
\hline $\begin{array}{l}\text { 6D363 } \\
\text { 6D367 }\end{array}$ & $\begin{array}{l}\text { Madera } \\
\text { Fresno }\end{array}$ & \\
\hline 6D371 & Tulare & This paper \\
\hline 6D378 & Kings & This paper \\
\hline
\end{tabular}

* UC, University of California, U.S.A.

Culture media. All strains were cultured on medium YDC lyeast extract (Difco), $10.0 \mathrm{~g}$; glucose, $20.0 \mathrm{~g}$; $\mathrm{CaCO}_{3}, 20.0 \mathrm{~g}$; Bacto-agar (Difco), 15.0 g; distilled water, $11 \mathrm{l}$ ) at $30^{\circ} \mathrm{C}$ for $48 \mathrm{~h}$ and then stored at $4{ }^{\circ} \mathrm{C}$. Medium 925E (Langley \& Kado, 1972) was used as a basal medium and medium 523 (Kado et al., 1972) for mass culture. The differential media employed were medium D3 (Kado \& Heskett, 1970), MacConkey agar (Difco), EMB agar (Difco) and modified EMB agar [glycerol, $10.0 \mathrm{ml}$; lactose, $10.0 \mathrm{~g}$; casein enzymatic hydrolysate (Calbiochem), $10.0 \mathrm{~g} ; \mathrm{K}_{2} \mathrm{HPO}_{4}, 2.0 \mathrm{~g}$; eosin $\mathrm{Y}, 0.4 \mathrm{~g}$; methylene blue, $0.065 \mathrm{~g}$; Bacto-agar, $15.0 \mathrm{~g}$; distilled water, 1 1].

Test for motility. Motility was observed in hanging drops prepared from exponential phase cultures in medium $\mathbf{5 2 3}$ broth. Air-dried films of the broth cultures were stained for the presence of flagella after Blenden \& Goldberg (1965).

Biochemical and physiological tests. Cytochrome oxidase (Kovacs, 1956) and catalase activity (Rhodes, 1959) were examined on cultures taken from medium 523 agar plates incubated for $24 \mathrm{~h}$ at $30^{\circ} \mathrm{C}$, and indole production was tested in medium 523 broth cultures after $48 \mathrm{~h}$ at $30^{\circ} \mathrm{C}$ (Happold \& Hoyle, 1934). Methyl red reaction was recorded according to the method of Barry et al. (1970) after $3 \mathrm{~d}$ growth in shake flasks of MR broth (peptone, $5.0 \mathrm{~g}$; glucose, $5.0 \mathrm{~g} ; \mathrm{K}_{2} \mathrm{HPO}_{4}, 5.0 \mathrm{~g}$; distilled water, 1 ) and glucose broth $\mathrm{NH}_{4} \mathrm{H}_{2} \mathrm{PO}_{4}$, $0.5 \mathrm{~g} ; \mathrm{K}_{2} \mathrm{HPO}_{4}, 0.5 \mathrm{~g} ; \mathrm{MgSO}_{4} .7 \mathrm{H}_{2} \mathrm{O}, 0.2 \mathrm{~g} ; \mathrm{NaCl}, 0.6 \mathrm{~g} ;$ yeast extract, $1.0 \mathrm{~g} ;$ glucose, $10.0 \mathrm{~g}$; distilled water, 11 ; pH 6.8), formulated by Dye (1968). The Voges-Proskauer test was recorded after $3 \mathrm{~d}$ (Coblentz, 1943). Lipase production was tested after $12 \mathrm{~d}$ growth by incorporating Tween 80 into medium 523 agar modified by replacing $\mathrm{K}_{2} \mathrm{HPO}_{4}$ with $2.0 \mathrm{~g} \mathrm{CaCl}_{2} 1^{-1}$; opacity around the areas of growth, due to the precipitation of calcium oleate, was recorded as a positive result (Sierra, 1957). Nitrate reductase activity was detected in nitrate agar slants (glucose, $10.0 \mathrm{~g} ; \mathrm{KNO}_{3}, 5.0 \mathrm{~g}$; yeast extract, $1.0 \mathrm{~g} ; \mathrm{K}_{2} \mathrm{HPO}_{4}, 2.0 \mathrm{~g} ; \mathrm{MgSO}_{4} .7 \mathrm{H}_{2} \mathrm{O}, 1.0 \mathrm{~g}$; Bacto-agar, $15.0 \mathrm{~g}$; distilled water, 1 l) using the reagents described by Bailey \& Scott (1974). Urease activity was detected after 24 and $48 \mathrm{~h}$ incubation (Christensen, 1946) and amino acid decarboxylases were detected in Bacto-decarboxylase broth base (Difco) and Moeller's medium B containing either $0.8 \%$ (w/v) L-arginine, L-lysine, L-ornithine or L-glutamic acid (Moeller, 1955). The deamination of phenylalanine and tryptophan was measured after $24 \mathrm{~h}$ according to Ewing $e$ t al. (1957) and Singer \& Volcani (1955) and $\beta$-galactosidase activity according to Holding \& Collee (1971). Protopectinase activity was observed on washed, peeled, alcohol-flamed, potato slices ( 5 to $7 \mathrm{~mm}$ thick) that were one-quarter immersed in sterile water and their surfaces streaked with bacteria; after 2 to $4 \mathrm{~d}$, complete collapse of the tissue designated a positive reaction. 2-Ketogluconate production in medium $925 \mathrm{E}$ salts containing 3\% $\mathrm{w} / \mathrm{v})$ potassium gluconate was scored according to Lelliott et al. (1966). The presence of arginine dihydrolase was determined in Thornley's (1960) medium after $7 \mathrm{~d}$ incubation at $30^{\circ} \mathrm{C}$ while the degradation of starch (Bailey \& Scott, 1974), hippurate (Brooks \& Hucker, 1944), aesculin (Dye, 1968) and gelatin (Smith et al., 1952) were observed after 9, 14, 24 
Table 2. Other bacteria studied

Species and strain

Source*

Klebsiella pneumoniae 3759, 3739 (oxytoca), 3744

Serratia marcescens 2875

Serratia plymuthica 3992

Serratia liquefaciens 3989

Shigella dysenteriae 2872

Shigella alkalescens 2026

Shigella flexneri 3538

Enterobacter cloacae 4021

Enterobacter agglomerans 3424

Enterobacter aerogenes 4022

Enterobacter aerogenes A-170-40

Salmonella typhimurium LT-2

Salmonella typhimurium

TA-1534, TA-1536, TA-1537, TA-1538

Salmonella typhimurium JL-1002

Erwinia carotovora B-374

E. carotovora 3D31

E. carotovora EC-201

Erwinia herbicola Y-46

E. herbicola $\mathrm{Y}-74$

$E$. herbicola 25D36

E. herbicola 25D38

Erwinia amylovora FB-1

E. amylovora 27-3

E. amylovora EA-167, EA-178

$E$. amylovora (NC)NYGA

Erwinia salicis ES-102

Erwinia nigrifluens 5D34, 5D36, 5D38

E. nigrifuens SD312, 5D313

Erwinia quercina UCBPP389, UCBPP400

Erwinia rhapontici 8D31

Source*
ICPB
ICPB
ICPB
ICPB
ICPB
ICPB
ICPB
ICPB
ICPB
ICPB
D. G. Gilchrist, UC Davis
J. L. Ingraham, UC Davis
B. N. Ames, UC Berkeley
A. Warren, UC Davis
P. F. Lurquin, Nuclear Centre, Mol, Belgium
R. H. Segall, USDA, Orlando, Fla, U.S.A.
M. N. Schroth, UC Berkeley
L. N. Gibbins, University of Guelph, Ont., Canada
L. N. Gibbins, University of Guelph, Ont., Canada
E. E. Wilson, UC Davis
W. Wescott, UC Davis
M. N. Schroth, UC Berkeley
S. V. Beer, Cornell University, N.Y., U.S.A.
ICPB
H. L. Keil, USDA, Beltsville, Md, U.S.A.
ICPB
E. E. Wilson, UC Davis
J. M. Gardner, UC Davis
M. N. Schroth, UC Berkeley
E. E. Wilson, UC Davis
ICP.

* ICPB, International Collection of Phytopathogenic Bacteria (M. P. Starr, curator), Davis, California, U.S.A.; UC, University of California, U.S.A.

and $31 \mathrm{~d}$ incubation, respectively. The formation of reducing substance from sucrose was determined after $48 \mathrm{~h}$ incubation at $30^{\circ} \mathrm{C}$ using the medium and method described by Dye (1968).

Bacteria were stabbed into and streaked over slants of triple sugar iron agar (TSI) and then incubated at $30^{\circ} \mathrm{C}$. The reactions were interpreted 18 to $24 \mathrm{~h}$ later based on the scheme presented by Hajna (1945).

Reactions in litmus milk were observed daily for $28 \mathrm{~d}$ (Bailey \& Scott, 1974) and levan production was identified by the method of Lelliott $e t$ al. (1966) from cultures grown at $30^{\circ} \mathrm{C}$ for $5 \mathrm{~d}$ on nutrient agar (Difco) or on medium 523 agar containing $5 \%(\mathrm{w} / \mathrm{v})$ sucrose. The ability of strains to grow in the presence of 1 to $10 \%(\mathrm{w} / \mathrm{v}) \mathrm{NaCl}$ (at $1 \%$ increments) and $0.1 \%(\mathrm{w} / \mathrm{v}) \mathrm{KCN}$ was recorded in medium 523 broth over $14 \mathrm{~d}$. Cultures showing turbidity were re-inoculated into medium containing the same $\mathrm{NaCl}$ or $\mathrm{KCN}$ concentration as a further check on growth.

Four media were selected to demonstrate the production of $\mathrm{H}_{2} \mathrm{~S}: 925 \mathrm{E}$ plus cysteine hydrochloride $(0.8 \mathrm{~g}$ $\left.1^{-1}\right)$, 925E plus sodium thiosulphate $\left(0.8 \mathrm{~g} \mathrm{l}^{-1}\right), 925 \mathrm{E}$ plus Bacto-peptone $\left(0.8 \mathrm{~g}^{-1}\right)$ and TSI. Cultures were incubated at $30^{\circ} \mathrm{C}$ for $9 \mathrm{~d}$ and the $\mathrm{H}_{2} \mathrm{~S}$ produced was detected by the filter paper strip method (Bailey \& Scott, 1974) or by the darkening of TSI medium (Hajna, 1945). Only the presence or absence of $\mathrm{H}_{2} \mathrm{~S}$ was scored but not more than once.

Sensitivity to antibiotics. Antibiotic-impregnated filter paper discs $(7 \mathrm{~mm}$ diam., Difco) were placed in the centre of medium 523 agar plates that had been overlaid with $3 \mathrm{ml} 0.7 \%$ molten agar containing $0.5 \mathrm{ml}$ portions of $24 \mathrm{~h}$ broth cultures. The antibiotics (Difco) used were chloramphenicol, neomycin, kanamycin, novobiocin and tetracycline (each at 5,10 and $30 \mu \mathrm{g} \mathrm{ml}^{-1}$ ), erythromycin $\left(2\right.$ and $15 \mu \mathrm{g} \mathrm{ml}^{-1}$ ), streptomycin ( 2 and $10 \mu \mathrm{g} \mathrm{ml}^{-1}$ ) and penicillin $\mathrm{G}$ ( 2 and 10 units). The plates were incubated at $30{ }^{\circ} \mathrm{C}$ for $24 \mathrm{~h}$ before measuring the diameter of the inhibition zone around the discs.

Sensitivity to colicins. Escherichia coli strains W3110 (ColE1), W3110 (ColE2) and W3110 (ColE3) (from D. R. Helinski, University of California, San Diego, U.S.A.) were each inoculated in the centre of medium 925 agar plates and incubated for $48 \mathrm{~h}$ at $30^{\circ} \mathrm{C}$. Each culture was then exposed to short-wave u.v. radiation from a UVII lamp (Ultraviolet Products, San Gabriel, Calif., U.S.A.) held 10 to $15 \mathrm{~cm}$ over the culture for 
20 to $25 \mathrm{~s}$ and incubated for 36 to $48 \mathrm{~h}$ at $30^{\circ} \mathrm{C}$ to induce synthesis of colicin. Then $0.5 \mathrm{ml}$ portions of the test bacteria were thoroughly mixed with $3 \mathrm{ml} 0.7 \%$ molten Bacto-agar and overlaid on the $E$. coli colicin producer. The plates were checked for a zone of growth inhibition around the $E$. coli colicin producer $24 \mathrm{~h}$ later.

Nutritional tests. Growth factor requirements were tested in minimal medium 925 and in medium 925 supplemented with $1.0 \mathrm{~g}$ yeast extract $\mathrm{l}^{-1}$. Growth in the presence of yeast extract (but not in its absence) within $14 \mathrm{~d}$ of incubation on a rotary shaker at room temperature indicated that growth factors were necessary.

Utilization of organic acids as sources of carbon and energy was tested in a medium containing: organic acid (see below), $10.0 \mathrm{~g} ;$ casein enzymatic hydrolysate, $2.0 \mathrm{~g} ; \mathrm{NaCl}, 5.0 \mathrm{~g} ; \mathrm{K}_{2} \mathrm{HPO}_{\mathrm{f}}, 0.3 \mathrm{~g} ; 1 \%$ (w/v) bromothymol blue, $3.0 \mathrm{ml}$; Bacto-agar, $10.0 \mathrm{~g}$; distilled water, 11 ; adjusted to $\mathrm{pH} 6.8$ before autoclaving the mixture. The organic acids used were: acetic, adipic, anthranilic, ascorbic, azelaic, benzoic, butyric, capric, caproic, caprylic, citric, deoxycholic, formic, fumaric, galacturonic, gluconic, glucuronic, glutaric, glycollic, heptanoic, itaconic, lactic, maleic, malic, malonic, mandelic, $m$-hydroxybenzoic, nicotinic, oxalic, polygalacturonic, propionic, protocatechuic, pyruvic, quinic, saccharic, salicylic, sebacic, suberic, succinic, tannic, tartaric and thioglycollic. All organic acids were used as sodium salts except gluconic acid which was used as the potassium salt. Cultures were checked daily for $3 \mathrm{~d}$ and a dark blue colour around the bacterial growth was considered positive. Uninoculated tubes and inoculated tubes lacking the organic acid but containing the other ingredients were used as controls. Subcultures from the positive tests to a second set of the test media were made to provide a check on false positive results attributable to possible carry-over of compounds in the initial inoculum.

Utilization of organic acids was also tested in the absence of dye, to avoid possible dye-mediated inhibition, by the following method. A medium was prepared as above but without bromothymol blue and its $\mathrm{pH}$ was adjusted to 6.8 after autoclaving. Inoculated plates were incubated at $30^{\circ} \mathrm{C}$ and checked for growth after $7 \mathrm{~d}$. Plates with all ingredients except the organic acid served as controls.

For utilization of rutin, Casamino acids and $\beta$-alanine as sources of carbon and energy, medium 925E agar with $2.0 \mathrm{~g} \beta$-alanine $1^{-1}$ or $5.0 \mathrm{~g}$ Casamino acids or rutin $\mathrm{H}^{-1}$ was used. $\beta$-Alanine and Casamino acids were filter-sterilized and added to autoclaved basal medium. Rutin was first dissolved in half the total volume of $0.1 \mathrm{M}-\mathrm{NaOH}$, the $\mathrm{pH}$ was adjusted to 8.0 and an equal volume of 925 basal medium was added before autoclaving. Plates were streaked with the bacterial cultures and checked for growth $7 \mathrm{~d}$ after incubation at $30^{\circ} \mathrm{C}$.

To test for utilization of carbohydrates and related compounds as sources of carbon and energy, medium 925 supplemented with yeast extract $(0.1 \%)$, bromocresol purple $\left(0.7 \mathrm{ml} \mathrm{of} \mathrm{a} 1.5 \%\right.$ solution $\left.\mathrm{l}^{-1}\right)$ and $0.5 \%$ (w/v) of the following compounds was used: amygdalin, D-cellobiose, D-fructose, D-fucose, D-galactose, D-glucose, D-lactose, D-maltose, D-mannitol, D-mannose, D-melibiose, D-melezitose, D-raffinose, D-ribose, D-sorbitol, D-sucrose, D-trehalose, D-xylose, dulcitol, aesculin, glycerol, i-inositol, inulin, L-arabinose, L-rhamnose, L-sorbose, salicin and starch. The medium was inoculated with the test strains and incubated at $30^{\circ} \mathrm{C}$. All tests were performed at least twice and cultures were examined for growth and acid production after 3, 7, 14 and $21 \mathrm{~d}$. A second medium containing Bacto-peptone (1\%), bromocresol purple $(0.7 \mathrm{ml}$ of a $1.5 \%$ solution $\left.1^{-1}\right)$ and $0.75 \%(\mathrm{w} / \mathrm{v})$ carbon source was prepared and adjusted to $\mathrm{pH} 6.8$ before autoclaving. Durham tubes were also used in glucose medium to detect gas formation. Growth and acid production were recorded after $3,7,14$ and $21 \mathrm{~d}$ incubation at $30^{\circ} \mathrm{C}$. In both methods, the controls consisted of uninoculated media and inoculated media without the carbon sources. At the end of all of the above experiments, culture purity was checked by streaking on YDC or medium 523 plates.

The ability of cultures to grow with amino acids as their sole carbon and nitrogen source was tested in the broth medium described by Dye (1968). Concentrated solutions of glycine and the L-amino acids alanine, arginine, asparagine, aspartic acid, cysteine, glutamic acid, glutamine, histidine, isoleucine, leucine, lysine, methionine, ornithine, phenylalanine, proline, serine, threonine, tryptophan and valine were filter-sterilized and added aseptically to give $0.4 \%(\mathrm{w} / \mathrm{v})$. Tubes were inoculated with a loopful of a $24 \mathrm{~h}$ bacterial suspension and examined for growth after $3,7,14$ and $24 \mathrm{~d}$ incubation with shaking at $30^{\circ} \mathrm{C}$. Growth was further checked by transferring a loopful of $24 \mathrm{~d}$ culture to fresh tubes of the amino acids media. Control tubes without added amino acids were also inoculated.

Numerical analysis. To code characters, most data collected from the 140 tests performed on 75 bacterial strains (Tables 1 and 2) that existed in one of two mutually exclusive states were assigned a code of 1 for a positive character and 0 for a negative character. The remaining multistate characters, such as pigmentation or colony morphology, were divided into several mutually exclusive states and strains were coded 1 for the particular character state exhibited and 0 for the others. The binary data were entered on standard IBM punched cards. The similarity coefficient (Sneath, 1957), defined as $S_{J}=\mathrm{NS} \times 100 /(\mathrm{NS}+\mathrm{ND})$, where NS is the number of positive characters common to a pair of organisms and ND is the number of unshared characters, and the matching coefficient (Sokal \& Michener, 1958), defined as $S_{S M}=(N S+N T) 100 /(N S+$ $N D+N T$ ), where NS and ND are the same as in $S_{J}$ and NT is the number of negative characters common to 
both organisms, were calculated using the computer programs outlined by Quadling (1970). Sorted similarity matrices were obtained using single linkage clustering assignments (Sneath \& Sokal, 1973). Data from $S_{J}, S_{s, s}$ and single linkage clustering were then used to prepare a sorted dendrogram. The homogeneity of the defined clusters and subclusters were checked by determining their mean intragroup and intergroup similarity values (Sneath, 1957).

DNA:DNA hybridization. Bacteria were grown in 41 Fernbach flasks containing $200 \mathrm{ml}$ medium 523 broth aerated by shaking at $225 \mathrm{rev} . \mathrm{min}^{-1}$ for $4 \mathrm{~d}$ at $28^{\circ} \mathrm{C}$, harvested by centrifugation, and washed twice with glass-distilled water. For labelled DNA, cells were grown in basal medium 925 salts containing glucose $(0.5 \%)$, deoxyadenosine $\left(200 \mu \mathrm{g} \mathrm{ml}^{-1}\right)$ and $\left[\right.$ methyl- $\left.{ }^{-3} \mathrm{H}\right]$ thymidine $\left[50 \mu \mathrm{Ci} \mathrm{ml}^{-1} ; 60 \mathrm{Ci} \mathrm{mmol}^{-1}(2.22 \mathrm{TBq}\right.$ $\left.\mathrm{mmol}^{-1}\right)$; New England Nuclear]. Yeast extract $(0.1 \mathrm{mg})$ was also added to the culture medium of Shigella flexneri because of its inability to grow in the absence of growth factors. Radioactively labelled cells were harvested by centrifugation during the late exponential phase (as judged by absorbance at $590 \mathrm{~nm}$ ) and washed with $0.05 \mathrm{M}$-sodium borate/0.01 M-EDTA buffer, pH 9.0. The packed cells from both media were stored in a frozen state overnight. DNA was prepared as outlined by Gardner \& Kado (1972). The final preparation of DNA was dissolved in $0.1 \times \mathrm{SSC}$ ( $\mathrm{SSC}$ buffer is $0.15 \mathrm{M}-\mathrm{NaCl}, 0.015 \mathrm{M}$-sodium citrate, pH 7.0), dialysed exhaustively against $0.1 \times \mathrm{SSC}$ and diluted to approximately $50 \mu \mathrm{g} \mathrm{ml}^{-1}$ with the same buffer. The purity of each DNA preparation was then checked by its absorbance spectrum, absorbance ratios at 260/280 $\mathrm{nm}$ and $260 / 230 \mathrm{~nm}$ and by measuring the helix to coil transition. Each preparation met the criteria standards for highly purified DNA (Gardner \& Kado, 1972; Flavell et al., 1974). Labelled DNA was dialysed against 0.01 M-sodium phosphate buffer, $\mathrm{pH} 6.8$, collected on hydroxylapatite and washed with 0.12 M-sodium phosphate buffer. The DNA was eluted with $0.6 \mathrm{M}$-sodium phosphate buffer and the eluted DNA was dialysed exhaustively against $0 \cdot 1 \times$ SSC.

Heat-denatured, non-labelled DNA was fixed to nitrocellulose filters (Schleicher \& Schüll Type B-6) as described by Drlica \& Kado (1974). The amount of DNA retained on $6 \mathrm{~mm}$ diam. filter discs cut from $47 \mathrm{~mm}$ diam. filters was determined by a diphenylamine method (Burton, 1968) but modified by increasing the acetaldehyde concentration three-fold to enhance the colour development.

Filters were placed individually in small vials and pretreated with the preincubation mixture of Denhardt (1966) for $8 \mathrm{~h}$ at $46^{\circ} \mathrm{C}$. The filters were then resuspended in $0.4 \mathrm{ml} 50 \%$ formamide $/ 5 \times$ SSC. Labelled DNA was sheared ultrasonically at $0^{\circ} \mathrm{C}$ using $30 \mathrm{~s}$ pulses with a Biosonik IV sonicator (Bronwill Co., Rochester, N.Y., U.S.A.) to fragments 500 to 600 nucleotides long (Studier, 1965). Sheared, heat-denatured, labelled DNA ( 1 to $2.5 \mu \mathrm{g}$ ) was then added to the above solution containing a filter and the mixture was incubated at $46^{\circ} \mathrm{C}$ with reciprocal shaking as described elsewhere (McConaughy et al., 1969). Each sample was in duplicate. Incubation, washing and isotope counting of the filters were done according to the procedures of Gardner \& Kado (1972). After counting, the filters were removed from the vials, placed in Kahn tubes to dry and the amount of DNA on each filter was determined by the diphenylamine method (Burton, 1968). Counts were then normalized per $\mu \mathrm{g}$ DNA and percentage DNA sequence homologies were calculated. For competitive hybridization, the reaction volume was increased to $0.6 \mathrm{ml}$, and $0.15 \mathrm{ml}$ of sheared, heat-denatured, unlabelled competitor DNA (total $150 \mu \mathrm{g}$ ) was added to the reaction mixture. Percentage competition was calculated by the equation of Gardner \& Kado (1972).

The melting curve of DNA was determined spectrophotometrically using a Beckman 5230 recording spectrophotometer equipped with specially designed thermal cuvette holders regulated by a temperature programmer (Gardner \& Kado, 1972). The absorbance and temperature were simultaneously recorded on a Honeywell X-Y recorder. The mol \% guanine plus cytosine (GC) of the DNA was calculated from $T_{m}$ values using the equation of Marmur \& Doty (1962).

\section{RESULTS}

In the similarity coefficient $\left(S_{j}\right)$ analysis, the 75 test strains were classified into three clusters - A, B and C - defined at the 46 to $55 \%$ similarity level (S-level, Fig. 1). Cluster A, which accommodated all erwiniae except Erwinia herbicola and $E$. carotovora strains, was further divided at the 58 to $63 \%$ S-level into subclusters a, b, c, and e and d. Cluster B was somewhat more heterogeneous than cluster $A$ and contained subclusters $f, g, h, i$ and $j$. Shigella dysenteriae and Shigella flexneri, which align at the $46 \%$ S-level, comprised cluster C. The mean intragroup similarity of each cluster and subcluster and the corresponding intergroup similarities are shown in Table 3 . The three clusters were well separated and the mean intragroup similarities were high. 


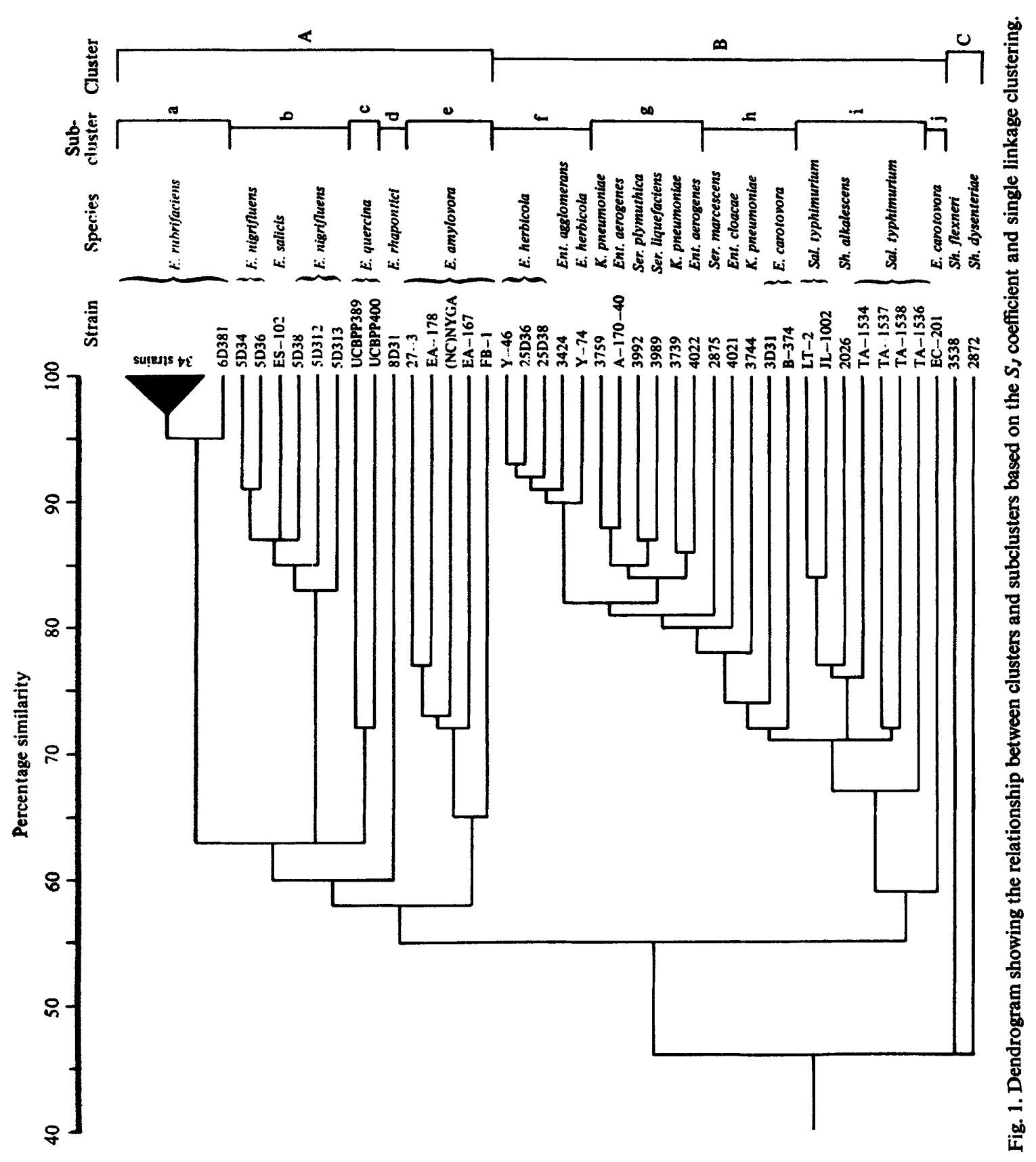


Table 3. Mean inter-and intragroup similarities (\%) for the defined clusters and subclusters in the similarity coefficient $\left(S_{J}\right)$ analysis

\begin{tabular}{|c|c|c|c|}
\hline $\begin{array}{r}\text { Cluster A } \\
\mathbf{B} \\
\mathbf{C}\end{array}$ & $\begin{array}{l}91.58 \\
39.00 \\
39.50\end{array}$ & $\begin{array}{l}78 \cdot 13 \\
31 \cdot 62\end{array}$ & $46 \cdot 0$ \\
\hline & A & B & \\
\hline
\end{tabular}

\begin{tabular}{|c|c|c|c|c|c|c|c|c|c|c|}
\hline $\begin{array}{r}\text { Subcluster a } \\
\text { b } \\
\text { c } \\
\text { d } \\
\text { e } \\
\text { f } \\
\text { g } \\
\text { h } \\
\mathbf{i} \\
\mathbf{j}\end{array}$ & $\begin{array}{l}94 \cdot 45 \\
56 \cdot 66 \\
54 \cdot 86 \\
47 \cdot 34 \\
50 \cdot 41 \\
42 \cdot 12 \\
37 \cdot 86 \\
40 \cdot 69 \\
38 \cdot 40 \\
38.97 \\
a\end{array}$ & $\begin{array}{c}85 \cdot 95 \\
51 \cdot 61 \\
55 \cdot 38 \\
42.92 \\
46.28 \\
43.00 \\
45 \cdot 81 \\
43.07 \\
48.68 \\
\text { b }\end{array}$ & $\begin{array}{c}72.09 \\
59.10 \\
49.94 \\
36.06 \\
32.83 \\
34.41 \\
32.81 \\
44.45 \\
c\end{array}$ & $\begin{array}{r}100 \cdot 00 \\
34 \cdot 90 \\
30 \cdot 72 \\
31 \cdot 39 \\
32 \cdot 54 \\
29 \cdot 74 \\
42 \cdot 19 \\
\text { d }\end{array}$ & $\begin{array}{c}74 \cdot 40 \\
36 \cdot 00 \\
32.04 \\
33.98 \\
33 \cdot 36 \\
42.81 \\
\mathrm{e}\end{array}$ & $\begin{array}{c}91 \cdot 23 \\
73.45 \\
67 \cdot 86 \\
56 \cdot 44 \\
44 \cdot 60 \\
f\end{array}$ & $\begin{array}{c}86 \cdot 80 \\
72 \cdot 10 \\
53 \cdot 12 \\
48 \cdot 82 \\
8\end{array}$ & $\begin{array}{c}70.59 \\
52.70 \\
49.56 \\
h\end{array}$ & $\begin{array}{c}68 \cdot 48 \\
35 \cdot 54 \\
\quad \text { i }\end{array}$ & $\begin{array}{c}100 \cdot 00 \\
j\end{array}$ \\
\hline
\end{tabular}

Table 4. Mean inter- and intragroup similarities (\%) for the defined clusters and subclusters in the matching coefficient $\left(S_{s x}\right)$ analysis

$\begin{array}{rcccc}\text { Cluster A } & 97.20 & & & \\ \text { B } & 65.93 & 82.15 & & \\ \text { C } & 59 \cdot 20 & 67.70 & 88.15 & \\ \text { D } & 71 \cdot 73 & 59.90 & 64.06 & 100.00 \\ & \text { A } & \text { B } & \text { C } & \text { D }\end{array}$

\begin{tabular}{|c|c|c|c|c|c|c|c|c|c|}
\hline $\begin{array}{r}\text { Subcluster a } \\
\text { b } \\
\text { c } \\
\text { d } \\
\text { e } \\
\text { f } \\
\text { g } \\
\text { h } \\
\text { i }\end{array}$ & $\begin{array}{c}98 \cdot 27 \\
83 \cdot 38 \\
79 \cdot 81 \\
82 \cdot 29 \\
81 \cdot 57 \\
79 \cdot 07 \\
63 \cdot 85 \\
55 \cdot 30 \\
62 \cdot 19 \\
\text { a }\end{array}$ & $\begin{array}{c}91 \cdot 43 \\
86 \cdot 43 \\
80 \cdot 72 \\
82 \cdot 57 \\
78 \cdot 57 \\
60-00 \\
51 \cdot 67 \\
58 \cdot 00 \\
\text { b }\end{array}$ & $\begin{array}{r}100.00 \\
82.62 \\
74 \cdot 71 \\
73.22 \\
54 \cdot 86 \\
50.12 \\
56 \cdot 29 \\
c\end{array}$ & $\begin{array}{c}94 \cdot 76 \\
76 \cdot 19 \\
74 \cdot 40 \\
66 \cdot 00 \\
58 \cdot 93 \\
65 \cdot 38 \\
\text { d }\end{array}$ & $\begin{array}{c}92 \cdot 11 \\
77 \cdot 64 \\
60 \cdot 26 \\
51 \cdot 21 \\
58 \cdot 20 \\
\text { e }\end{array}$ & $\begin{array}{c}83 \cdot 57 \\
58 \cdot 93 \\
47 \cdot 62 \\
55 \cdot 65 \\
\text { f }\end{array}$ & $\begin{array}{c}94 \cdot 51 \\
76 \cdot 52 \\
76 \cdot 54 \\
\mathrm{~g}\end{array}$ & $\begin{array}{c}90 \cdot 11 \\
79 \cdot 36 \\
\mathbf{h}\end{array}$ & $\begin{array}{c}78.97 \\
\text { i }\end{array}$ \\
\hline
\end{tabular}

Thirty-five strains of $E$. rubrifaciens, sharing very high similarity with one another, were recovered at the $95 \%$ S-level in subcluster a (Fig. 1). Subcluster b, defined at the 83 to $91 \%$ S-level, was composed of $E$. nigrifluens strains and $E$. salicis. Subcluster c, containing strains of $E$. quercina, shared relatively high similarity with subcluster d (Table 3 ) which accommodated the $E$. rhapontici strain. Erwinia amylovora strains were recovered in subcluster e, defined at a 65 to $77 \%$ S-level. Erwinia herbicola strains and Enterobacter agglomerans comprised a relatively tight subcluster, f, defined at the 90 to $93 \%$ S-level. Klebsiella pneumoniae 3759 and 3739, Serratia plymuthica, Serratia liquefaciens and Enterobacter aerogenes were classified in subcluster $\mathrm{g}$, while Klebsiella pneumoniae 3744, Serratia marcescens, Enterobacter cloacae and $E$. carotovora formed subcluster $h$ which was defined at the 72 to $81 \%$ S-level. High intergroup similarities were obtained for subclusters $f, g$ and $h$ (Table 3). The strains in subcluster i, defined at the 67 to $84 \% \mathrm{~S}$-level, formed a relatively loose group which included Shigella alkalescens 2026 and all Salmonella typhimurium strains. Erwinia carotovora EC-201, sharing little similarity with the other two $E$. carotovora strains in subcluster $h$, comprised subcluster $\mathrm{j}$.

Examination of the data by the matching coefficient $\left(S_{s L}\right)$ produced the same subclusters defined at higher S-levels (Fig. 2). The grouping of the subclusters into clusters, however,

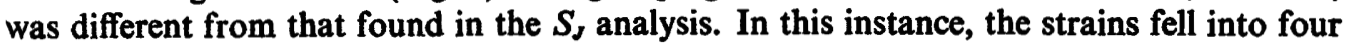
clusters - A, B, C and D - at the 77 to $80 \%$ S-level. Shigella dysenteriae 2872 and Shigella 

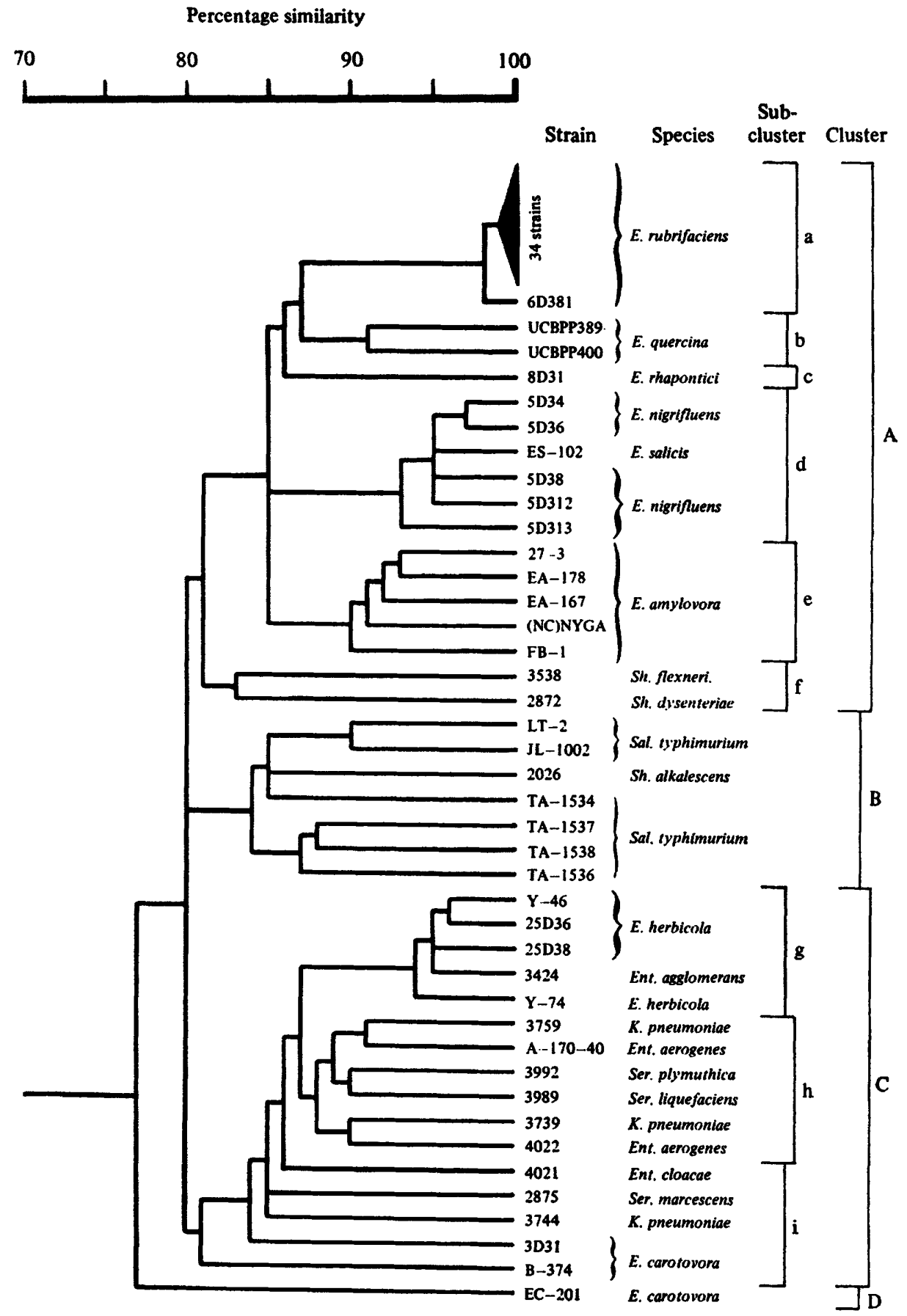

Fig. 2. Dendrogram showing the relationship between clusters and subclusters based on the $S_{S M}$ coefficient and single linkage clustering. 
Table 5. Percentage GC values for DNA preparations and DNA homologies (\%) between Erwinia rubrifaciens strains 6D34, 6D332, 6D337, 6D371 and 6D379 and some members of the family Enterobacteriaceae

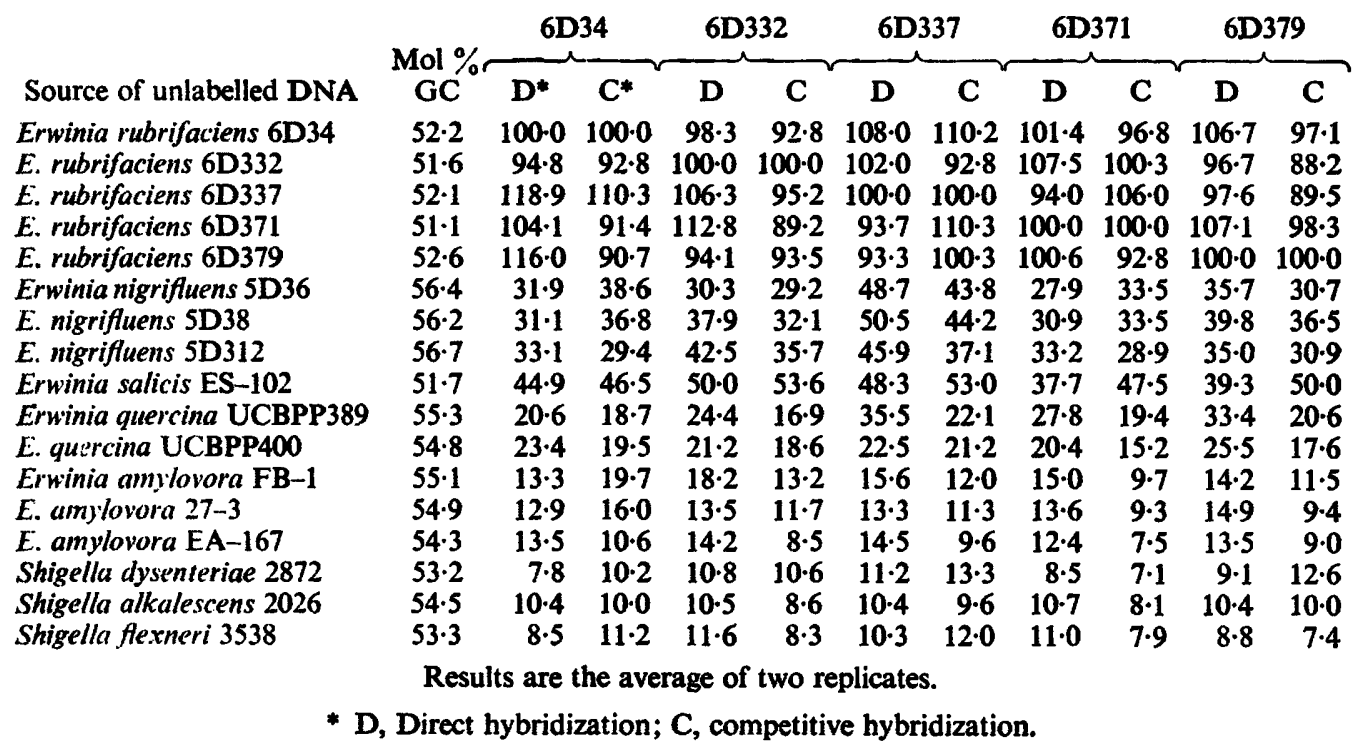

fexneri 3538 were included in cluster A because of their relatively high similarities with the members of that cluster, while Salmonella typhimurium strains and Shigella alkalescens 2026 were recovered together distinctly enough to warrant the rank of a cluster (cluster B). Erwinia carotovora EC-201 was assigned to a new group, cluster D.

The mean inter- and intragroup similarities of the clusters and subclusters in the matching coefficient $\left(S_{S U}\right)$ analysis are presented in Table 4.

\section{DNA: DNA hybridization}

The mol $\% \mathrm{GC}$ values of the DNA (Table 5) indicated that a fairly wide range of values (from 51 to $57 \%$ ) exists within the Erwinia strains tested.

The direct hybridization data (Table 5) showed that the five randomly selected strains of E. rubrifaciens were extremely closely related. The relative homologies between $E$. rubrifaciens strains and other test organisms was under $50 \%$ in all cases. Erwinia rubrifaciens was most closely related to $E$. salicis. These organisms exhibited $44 \%$ average relatedness. Erwinia nigrifluens was somewhat less related to $E$. rubrifaciens ( $37 \%$ average binding) and $E$. quercina ranked third in relatedness to $E$. rubrifaciens ( $26 \%$ average binding). The average degree of relatedness between $E$. rubrifaciens and E. amylovora, Shigella dysenteriae 2872 Shigella alkalescens 2026 and Shigella flexneri 3538 was about $11 \%$.

Relatedness patterns similar to that of $E$. rubrifaciens were obtained in cross hybridization using reference DNA from E. nigrifluens 5D38 and Shigella flexneri 3538 (Table 6). The three $E$. nigrifluens strains used in this study were indistinguishable. Shigella flexneri 3538 and Shigella dysenteriae 2872 were highly interrelated $(85 \%)$; the relatedness between Shigella flexneri 3538 and Shigella alkalescens 2026 was lower (about $55 \%$ ).

Results of competitive hybridization experiments agreed with those of direct hybridization and percentage homologies fell in the same range as those of direct hybridization (Tables 5 and 6). Percentage homologies between $E$. rubrifaciens and $E$. nigrifluens strains were almost the same as those from direct hybridization. Percentage homologies between $E$. 
Table 6. DNA homologies (\%) between Erwinia nigrifluens 5D38 and Shigella flexneri 3538 and some members of the family Enterobacteriaceae

\begin{tabular}{|c|c|c|c|c|}
\hline \multirow[b]{2}{*}{ Source of unlabelled DNA } & \multicolumn{2}{|c|}{ E. nigrifluens 5D38 } & \multicolumn{2}{|c|}{ S. flexneri 3538} \\
\hline & $\mathbf{D}^{*}$ & $C^{*}$ & $\mathbf{D}$ & $\mathbf{C}$ \\
\hline Erwinia rubrifaciens 6D34 & $33 \cdot 3$ & $35 \cdot 0$ & $10 \cdot 5$ & $\mathbf{9 \cdot 2}$ \\
\hline E. rubrifaciens 6D332 & $33 \cdot 8$ & $34 \cdot 6$ & $9 \cdot 2$ & $11 \cdot 2$ \\
\hline E. rubrifaciens 6D337 & 47.9 & $37 \cdot 7$ & $11 \cdot 0$ & $11 \cdot 4$ \\
\hline E. rubrifaciens 6D371 & $27 \cdot 2$ & $27 \cdot 3$ & $9 \cdot 3$ & $9 \cdot 4$ \\
\hline E. rubrifaciens 6D379 & $41 \cdot 3$ & $40 \cdot 2$ & $6 \cdot 5$ & 12.9 \\
\hline Erwinia nigrifluens 5D36 & $92 \cdot 0$ & $108 \cdot 1$ & 6.8 & 14.8 \\
\hline E. nigrifluens 5D38 & $100-0$ & $100 \cdot 0$ & 6.9 & $12 \cdot 9$ \\
\hline E. nigrifuens SD 312 & $103 \cdot 3$ & $92 \cdot 7$ & 6.9 & $12 \cdot 7$ \\
\hline Erwinia salicis ES-102 & $27 \cdot 0$ & $38 \cdot 5$ & $5 \cdot 8$ & $11 \cdot 1$ \\
\hline Erwinia quercina UCBPP389 & $18 \cdot 1$ & $25 \cdot 2$ & $7 \cdot 6$ & $10 \cdot 4$ \\
\hline E. quercina UCBPP400 & $13 \cdot 1$ & $22 \cdot 2$ & $4 \cdot 9$ & $12 \cdot 9$ \\
\hline Erwinia amylovora FB-1 & $14 \cdot 9$ & $14 \cdot 5$ & $13 \cdot 3$ & $10 \cdot 2$ \\
\hline E. amylovora $27-3$ & 15.9 & $13 \cdot 4$ & $7 \cdot 6$ & $13 \cdot 5$ \\
\hline E. amylovora EA-167 & $16 \cdot 0$ & $10 \cdot 2$ & 6.9 & $14 \cdot 6$ \\
\hline Shigella dysenteriae 2872 & $7 \cdot 0$ & $10-5$ & 84.9 & 72.9 \\
\hline Shigella alkalescens 2026 & $5 \cdot 7$ & $9 \cdot 8$ & $54 \cdot 4$ & $53 \cdot 8$ \\
\hline Shigella flexneri 3538 & $7 \cdot 5$ & $10 \cdot 1$ & $100 \cdot 0$ & $100 \cdot 0$ \\
\hline
\end{tabular}

Results are the average of two replicates.

* D, Direct hybridization; C, competitive hybridization.

rubrifaciens strains and $E$. salicis ES-102 increased, whereas those between $E$. rubrifaciens strains and $E$. quercina strains decreased in competitive hybridization (Tables 5 and 6).

\section{DISCUSSION}

Erwinia rubrifaciens strains formed a very tight, distinct subcluster (Figs 1 and 2) with a mean intragroup similarity of $\mathbf{9 4 . 5}$ and $98.3 \%$ in similarity coefficient and matching coefficient analyses, respectively (Tables 3 and 4). The data do not support an earlier proposal to reclassify erwiniae within existing taxa in the Enterobacteriaceae because the erwiniae separated into subclusters quite distinct from those containing other enterobacteria (Moustardier et al., 1961). All erwiniae have been placed into three arbitrary groups 'amylovora', 'carotovora' and 'herbicola' based primarily on their pathogenic traits (Dye, 1968, 1969a, $b, c$; Lelliott, 1974). Numerical taxonomic studies (Focht \& Lockhart, 1965; Krieg \& Lockhart, 1966; Komagata et al., 1968; Goodfellow et al., 1976) and DNA pairing experiments (Brenner et al., 1972; Gardner \& Kado, 1972; Brenner, 1973; Brenner et al., 1973, 1974) have shown that these groups are distinct from one another and from other enteric taxa, but the rationale behind further grouping many erwiniae under arbitrarily selected species is not supported by these studies, which, in fact, show that erwiniae comprise a very heterogeneous group easily separable by present analytical systems. Thus, the earlier proposal that $E$. rubrifaciens, $E$. nigrifluens, $E$. salicis and $E$. quercina should be considered as varieties of $E$. amylovora (Dye, 1968) is not supported by more recent DNA:DNA hybridization studies (Gardner \& Kado, 1972; Brenner et al., 1972; Murata \& Starr, 1974) and the present numerical taximetric analyses (Tables 3 and 4). The recovery of these species as separate subclusters is also at variance with the recent proposal of Young et al. (1978b), who view $E$. rubrifaciens as a pathovar of $E$. quercina. In fact, the mean intergroup similarities (Tables 3 and 4 ) show that $E$. quercina, $E$. nigrifluens and $E$. salicis are almost equally related to $E$. rubrifaciens. If, for example, bacteria in subclusters $b, f, g, h$ and $i$ (Fig. 1 ) with much higher intragroup similarities are considered separate species, then it is clear that $E$. quercina and $E$. rubrifaciens with much lower similarities each deserve species status. 
It is well-known that test errors can distort similarity coefficients (Sneath \& Johnson, 1972). The degree of confidence that can be placed in a classification is a reflection of the congruence found between the different types of information (Goodfellow \& Alderson, 1977; Goodfellow et al., 1978). The recovery of well-defined and homogeneous clusters and subclusters in the present study indicates that the test error has been within acceptable limits.

DNA:DNA reassociation analyses clearly demonstrate excellent agreement between nucleotide sequence homology and numerical phenetic data (e.g. Gross \& Wayne, 1970; Sneath, 1972; Staley \& Colwell, 1973; Colwell et al., 1974; Mordarski et al., 1976). The present results fully confirm this observation for plant pathogenic erwiniae. Representative strains of the species recovered in the cluster A (Fig. 2) were randomly selected and used in the DNA:DNA hybridization experiments. A fairly wide range of mol $\% \mathrm{GC}$ values (from 51 to $57 \%$ ) exists among the bacteria tested. No distinct relationships between GC values and DNA homology data were found.

Erwinia rubrifaciens strains possess almost identical genomes as judged by extremely high DNA homologies (Table 5). This correlates well with the grouping of $E$. rubrifaciens strains in a very tight, distinct, subcluster in the phenetic numerical analyses (Figs 1 and 2).

Gardner \& Kado (1972), Brenner et al. (1972) and Murata \& Starr (1974) found that in the white, non-pectolytic phytopathogen group, $E$. rubrifaciens, $E$. salicis and $E$. nigrifluens formed a rather loose cluster (the rubrifaciens-salicis cluster), whereas $E$. quercina and $E$. amylovora were apparently independent of the rubrifaciens-salicis cluster and of each other. In the present studies, the homologies shown by strains of $E$. salicis and $E$. nigrifluens with $E$. rubrifaciens and those shown by $E$. rubrifaciens and $E$. salicis with $E$. nigrifuens confirm and extend the earlier findings. As expected, higher DNA homologies were observed between $E$. rubrifaciens and $E$. quercina than between $E$. rubrifaciens and $E$. amylovora (Table 5). It should be stressed that the $E$. amylovora strains and the two Shigella species seem to share about the same level of core relatedness (around $10 \%$ ) with $E$. rubrifaciens in the present study as they do with the other members of the Enterobacteriaceae (Brenner et al., 1972; Gardner \& Kado, 1972; Murata \& Starr, 1974).

The higher DNA homology between $E$. rubrifaciens and $E$. salicis, a pathogen of willow, than between $E$. rubrifaciens and $E$. nigrifluens, both pathogens of the English walnut, suggests no co-evolutionary selection between the pathogen and its host, otherwise $E$. salicis would also be a pathogen of walnut. Furthermore, E. rubrifaciens strains are invariant, irrespective of where they originated, indicating that they may have come from a single source rather than multiple sources long ago.

The authors thank James E. DeVay, W. Harley English and John M. Gardner for helpful discussions during the preparation of this manuscript. Special thanks are due to Frank Schick and Jeff Hall for technical assistance.

\section{REFERENCES}

BaILeY, W. R. \& ScotT, E. G. (1974). Diagnostic Microbiology. St. Louis: The C. V. Mosby Co.

Barry, A. L., Bernsohm, K. L., Adams, A. P. \& THRUPP, L. D. (1970). Improved 18-hour methyl red test. Applied Microbiology 20, 866-870.

Blenden, D. C. \& Goldberg, H. S. (1965). Silver impregnation stain for Leptospira and flagella. Journal of Bacteriology 89, 899-900.

Brenner, D. J. (1973). Deoxyribonucleic acid reassociation in the taxonomy of enteric bacteria. International Journal of Systematic Bacteriology 23, 298-307.

Brenner, D. J., Fanning, G. R. \& Steigerwalt,
A. G. (1972). Deoxyribonucleic acid relatedness among species of Erwinia and between Erwinia species and other enterobacteria. Journal of Bacteriology 110, 12-17.

Brenner, D. J., Steigerwalt, A. G., Mulos, G. V. \& Fanning, G. R. (1973). Deoxyribonucleic acid relatedness among erwiniae and other enterobacteriaceae: the soft rot organisms (genus Pectobacterium Waldee). International Journal of Systematic Bacteriology 23, 205-216.

Brenner, D. J., Fanning, G. R. \& Steigerwalt, A. G. (1974). Deoxyribonucleic acid relatedness among erwiniae and other enterobacteriaceae: the 
gall, wilt, and dry necrosis organisms (genus Erwinia Winslow et al., sensu stricto). International Journal of Systematic Bacteriology 24, 197-204.

Brooks, R. F. \& Hucker, G. J. (1944). A study of certain members of the genus Corynebacterium. Journal of Bacteriology 48, 295-312.

Burton, K. (1968). Determination of DNA concentration with diphenylamine. Methods in Enzymology 12, 163-166.

Christensen, W. B. (1946). Urea decomposition as a means of differentiating Proteus and paracolon cultures from each other and from Salmonella and Shigella types. Journal of Bacteriology 52, 461466.

Coblentz, L. M. (1943). Rapid detection of the production of acetylmethylcarbinol. American Journal of Public Health 33, 815-817.

Colwell, R. R., Johnson, R., Wan, L., Lovelace, T. E. \& BRENNER, D. J. (1974). Numerical taxonomy and deoxyribonucieic acid reassociation in the taxonomy of some Gram-negative fermentative bacteria. International Journal of Systematic Bacteriology 24, 422-433.

DenhaRdT, D. T. (1966). A membrane filter technique for the detection of complementary DNA. Biochemical and Biophysical Research Communications 23, 641-646.

DrlicA, K. A. \& KADO, C. I. (1974). Quantitative estimation of Agrobacterium tumefaciens DNA in crown gall tumor cells. Proceedings of the National Academy of Sciences of the United States of America 71, 3677-3681.

DYE, D. W. (1968). A taxonomic study of the genus Erwinia. I. The 'amylovora' group. New Zealand Journal of Science 11, 590-607.

DYE, D. W. (1969a). A taxonomic study of the genus Erwinia. II. The 'carotovora' group. New Zealand Journal of Science 12, 81-97.

DYE, D. W. (1969b). A taxonomic study of the genus Erwinia. III. The 'herbicola' group. New Zealand Journal of Science 12, 223-236.

DYE, D. W. (1969c). A taxonomic study of the genus Erwinia. IV. Atypical erwinias. New Zealand Journal of Science 12, 833-839.

Ewing, W. H., Davis, B.R. \& Reavis, R. W. (1957). Phenylalanine and malonate media and their use in enteric bacteriology. Public Health Laboratory 15, 153-166.

Flavell, R. A., Birfelder, E. J., Sanders, J. P. M. \& BORST, P. (1974). DNA-DNA hybridization on nitrocellulose filters. 1. General considerations and non-ideal kinetics. European Journal of Biochemistry 47, 535-543.

Focht, D. D. \& LockhaRT, W. R. (1965). Numerical survey of some bacterial taxa. Journal of Bacterio$\log y$ 90, 1314-1319.

GARDNER, J. M. \& KADo, C. I. (1972). Comparative base sequence homologies of the deoxyribonucleic acid of Erwinia species and other enterobacteriaceae. International Journal of Systematic Bacterio$\log y$ 22, 201-209.

GARDNER, J. M. \& KADO, C. I. (1973). Evidence for systemic movement of Erwinia rubrifaciens in Persian walnuts by the use of double-antibiotic markers. Phytopathology 63, 1085-1086.

Goodfellow, M. \& Alderson, G. (1977). The actinomycete-genus Rhodococcus: a home for the 'rhodochrous' complex. Journal of General Microbiology 100, 99-122.

Goodfellow, M., Austin, B. \& Dickinson, C. H. (1976). Numerical taxonomy of some yellowpigmented bacteria isolated from plants. Journal of General Microbiology 97, 219-233.

Goodfellow, M.,ORlean, P. A. B., Collins, M. D., Alshamaony, L. \& Minnikin, D. E. (1978). Chemical and numerical taxonomy of strains received as Gordona aurantiaca. Journal of General Microbiology 109, 57-68.

Gross, N. M. \& WAYNE, L. G. (1970). Nucleic acid homology in the genus Mycobacterium. Journal of Bacteriology 104, 630-634.

HaJNA, A. A. (1945). Triple-sugar iron agar medium for the identification of the intestinal group of bacteria. Journal of Bacteriology 49, 516-517.

Happold, F. C. \& HoYLe, L. H. (1934). The quantitative determination of indole in bacterial cultures. Biochemical Journal 28, 1171-1172.

Holding, A. J. \& ColleE, J. G. (1971). Routine biochemical tests. Methods in Microbiology 6, 1-32.

KADO, C. I. \& GARDNER, M. M. (1977). Transmission of deep bark canker of walnuts by the mechanical harvester. Plant Disease Reporter 61, 321-325.

KaDO, C. I. \& HesketT, M. G. (1970). Selective media for isolation of Agrobacterium, Corynebacterium, Erwinia, Pseudomonas, and Xanthomonas. Phytopathology 60, 969-976.

Kado, C. 1., Hesket, M. G. \& Langley, R. A. (1972). Studies on Agrobacterium tumefaciens: characterization of strains $1 \mathrm{D} 135$ and B6, and analysis of the bacterial chromosome transfer RNA and ribosomes for tumor-inducing ability. Physiological Plant Pathology 2, 47-57.

KaDO, C. I., DUTRA, J. C., MOlleR, W. J. \& Ramos, D. E. (1977). An assessment of the susceptibility of various walnut cultivars to deep bark canker. Journal of the American Society for Horticultural Sciences 102, 698-702.

Komagata, K., Tamagawa, $Y$. \& Kocur, $M$. (1968). Differentiation of Erwinia amylovora, Erwinia carotovora, and Erwinia herbicola. Journal of General and Applied Microbiology 14, 39-45.

Kovacs, N. (1956). Identification of Pseudomonas pyocyanea by the oxidase reaction. Nature, London 178, 703.

KRIEG, R. E. \& Lockhart, W. R. (1966). Classification of enterobacteria based on overall similarity. Journal of Bacteriology 92, 1275-1280.

LANGley, R. A. \& Kado, C. I. (1972). Studies on Agrobacterium tumefaciens, conditions for mutagenesis by $N$-methyl- $N^{\prime}$-nitro- $N$-nitrosoguanidine and relationships of $A$. tumefaciens mutants to crown-gall tumor induction. Mutation Research 14, 277-286.

Lelliott, R. A. (1974). Genus XII. Erwinia Winslow, Broadhurst, Buchanan, Krumwiede, Rogers and Smith 1920, 209. In Bergey's Manual of Determinative Bacteriology, 8th edn., pp. 332-339. Edited by $R$. E. Buchanan \& N. E. Gibbons. Baltimore, U.S.A.: Williams \& Wilkins.

Lelliott, R. A., Billing, E. \& HaYward, A. C. (1966). A determinative scheme for the fluorescent plant pathogenic pseudomonads. Journal of Applied Bacteriology 29, 470-489. 
MARMUR, J. \& DoTY, P. (1962). Determination of the base composition of deoxyribonucleic acid from its thermal denaturation temperature. Journal of Molecular Biology 5, 109-118.

McConaughy, B., Laird, C. D. \& McCarthy, B. J. (1969). Nucleic acid reassociation in formamide. Biochemistry 8, 3289-3295.

MOELLER, V. (1955). Simplified tests for some amino acid decarboxylases and for the arginine dihydrolase system. Acta pathologica et microbiologica scandinavica 36, 158-172.

Mordarski, M., Szyba, K., Pulverer, G. \& GoodFELLOW, M. (1976). Deoxyribonucleic acid reassociation in the classification of the "rhodochrous' complex and allied taxa. Journal of General Microbiology 94, 235-245.

Moustardier, G., Brisou, J., SOUt, J. \& EhrhardT, J. P. (1961). Les Erwinia. Discussion taxonomique Intérêt Medical. Bulletin de l'Association des diplomés de microbiologie de la Faculté de pharmacie de Nancy 82, 3-12.

Murata, N. \& StarR, M. P. (1974). Intrageneric clustering and divergence of Erwinia strains from plants and man in the light of deoxyribonucleic acid segmental homology. Canadian Journal of Microbiology 20, 1545-1565.

QuADLING, C. (1970). Analyzing the data. In Methods for Numerical Taxonomy, pp. 34-47. Edited by W. R. Lockhart \& J. Liston. Washington: American Society for Microbiology.

RHodes, M. E. (1959). The characterization of Pseudomonas fluorescens. Journal of General Microbiology 21, 221-263.

SCHAAD, N. W. \& WILSON, E. E. (1970a). Survival of Erwinia rubrifaciens in soil. Phytopathology 60, 557-558.

SchaAd, N. W. \& Wilson, E. E. (1970b). Pathological anatomy of the bacterial phloem canker disease of Juglans regia. Canadian Journal of Botany 48, 1055-1060.

ScHAAD, N. W. \& Wilson, E. E. (1971 a). Bacterial phloem canker of Persian walnut, development and control factors. California Agriculture 25, 4-7.

SchaAd, N. W. \& Wilson, E. E. (1971b). The ecology of Erwinia rubrifaciens and development of phloem canker of Persian walnut. Annals of Applied Biology 69, 125-136.

SchaAd, N. W., Heskett, M. G., Gardner, J. M. \& KADO, C. I. (1973). Influence of inoculum dosage, time after wounding, and season of infection of Persian walnut trees by Erwinia rubrifaciens. Phytopathology 63, 327-329.

SterRA, G. (1957). A simple method for the detection of lipolytic activity of micro-organisms and some observations on the influence of the contact between cells and fatty substrates. Antonie van Leeuwenhoek 23, 15-22.

Singer, J. \& VolCaNI, B. E. (1955). An improved ferric chloride test for differentiating ProteusProvidencia group from other Enterobacteriaceae. Applied Microbiology 24, 449-452.

Smith, N. R., Gordon, R. E. \& ClaRK, F. E. (1952). Aerobic sporeforming bacteria. U.S. Department of Agriculture Monograph 16, 1-148.

SNEATH, P. H. A. (1957). The application of computers to taxonomy. Journal of General Microbiology 17, 201-226.

SNEATH, P. H. A. (1972). Computer taxonomy. Methods in Microbiology 7A, 29-98.

SNeath, P. H. A. \& Johnson, R. (1972). The influence on numerical taxonomic similarities of errors in microbiological tests. Journal of General Microbiology 72, 377-392.

SNeAtH, P. H. A. \& Sokal, R. R. (1973). Numerical taxonomy. The Principles and Practice of Numerical Classification. San Francisco: W. H. Freeman.

SOKAL, R. R. \& MiChener, C.D. (1958). A statistical method for evaluating systematic relationships. University of Kansas Science Bulletin 38, 14091438.

Staley, T. E. \& Colwell, R. R. (1973). Deoxyribonucleic acid reassociation among members of the genus Vibrio. International Journal of Systematic Bacteriology 23, 316-332.

STUDIER, F. W. (1965). Sedimentation studies of the size and shape of DNA. Journal of Molecular Biology 11, 373-390.

THORNLEY, M. J. (1960). The differentiation of Pseudomonas from other Gram-negative bacteria on the basis of arginine metabolism. Journal of Applied Bacteriology 23, 37-52.

Wilson, E. E., ZeIToun, F. M. \& Fredrickson, D. L. (1967). Bacterial phloem canker, a new disease of Persian walnut trees. Phytopathology 57, 618-621.

Young, J. M., Dye, D. W., Bradbury, J. F., Panagopoulos, C. G. \& Robas, C. F. (1978a). The use of the term 'Pathovar' in the classification of plant pathogenic bacleria. Proceedings of the Fourth International Conference on Plant Pathogenic Bacteria, Angers, pp. 359-363.

YounG, J. M., DYe, D. W., Bradbury, J. F., Panagopoulos, C. G. \& Robbs, C. F. (1978b). A proposed nomenclature and classification for plant pathogenic bacteria. New Zealand Journal of Agricultural Research 21, 153-177. 